\title{
Unpacking Recommendation 16 of the Health Ombud's report on the Life Esidimeni tragedy
}

The Health Ombud released the 'Report into the circumstances surrounding the deaths of mentally ill patients transferred from Life Esidimeni to community-based facilities, Gauteng province' on 1 February 2017. ${ }^{[1]}$ The past year has been filled with activity as his recommendations have been implemented: data on mental healthcare users (MHCUs) have been collected, survivors have been re-hospitalised in newly contracted long-stay beds, and efforts have been made to locate those lost to the system. Forensic services have begun examining causes of death, and the South African Police Service, Special Investigations Unit and Human Rights Commission have commenced investigations into the process and its outcomes. Finally, closing arguments have been made at the Life Esidimeni Arbitration, which gave graphic description to the tragedy.

Recommendation 16 of the Health Ombud's report, which speaks to the future of mental healthcare in South Africa (SA), however, remains to be addressed. It recognises that for deinstitutionalisation to be undertaken properly ... community based mental health care services must be focused upon, must be resourced and must be developed .... [1] Given the lack of understanding of the links between deinstitutionalisation, community-based mental health services and the budget made apparent at the arbitration hearings, we believe that Recommendation 16 deserves unpacking for proper implementation to occur.

Firstly, deinstitutionalisation is not a new concept in SA. The term 'deinstitutionalisation' belongs to a shift in mental health practice that began in Europe and the USA in the 1950s and refers to the change in care setting from specialised institutions to community-based facilities. Having inherited a colonial-era custodial-care mental health system, SA built institutions for the care of the severely mentally ill and disabled. It began deinstitutionalising its severely mentally ill in the mid-1990s, in response to the human right of MHCUs to receive care close to their homes. ${ }^{[2]}$

The pace of deinstitutionalisation escalated following the promulgation of the Mental Health Care Act 17 of 2002, ${ }^{[3]}$ but it was not accompanied by the development of community psychiatry. ${ }^{[4]}$ The National Mental Health Policy Framework and Strategic Plan $2013-2020^{[5]}$ recognises this imbalance when it states on page 16 that 'Deinstitutionalisation has progressed at a rapid rate in South Africa, without the necessary development of community-based services. This has led to a high number of homeless mentally ill, people living with mental illness in prisons and revolving door patterns of care.' The transfer of so many MHCUs from Life Esidimeni to ill-prepared nongovernmental organisations (NGOs) represented the closure of the last remaining long-stay beds. It represented the completion of rapid, poorly planned deinstitutionalisation in the province, not the beginning.

Secondly, the NGOs to which Life Esidimeni MHCUs were transferred are not themselves 'community-based mental health services', but 'supported housing' run by NGOs that should operate within the community-based mental health service system. They serve as homes for mentally disabled people who, for whatever reason, cannot live with their families. They should provide structure, routine and security; a place in which the person may live within their community and hopefully have a sense of purpose and quality of life. As such, most NGOs do not themselves provide healthcare; they should access healthcare from the local general and mental health services.
As indicated in Recommendation 16, community-based mental health services comprise both integrated primary mental healthcare and community-based psychiatric care. They need to include specialist psychiatric expertise for people with severe mental illness, primary care of people with uncomplicated mental illness, and general healthcare of the mentally disabled. These services support the NGOs, ideally offering rehabilitation outreach, education and supervision to caregivers in the NGOs.

In her testimony at the Arbitration, MEC for Finance Barbara Creecy provided key insights into the budget for mental healthcare in Gauteng. She described how the mental health budget is scattered among different programmes in the budget. This could explain why money has not 'followed the patient' in the deinstitutionalisation process - an institution budget may not follow the patient to the community, which falls under district health services. She testified that ZAR1.4 billion (3.5\% of the Gauteng Province health budget) was allocated to mental health in Gauteng for the 2017/18 financial year. This is considerably less than the World Health Organization's recommended $5 \%{ }^{[6]}$ She found that the budget for community-based mental health services has been reduced over the past few years, while that for psychiatric hospitals increased. This is consistent with an analysis of the Gauteng community mental health services, which found that staffing of district psychiatric clinics was reduced between 2005 and 2015 despite an increase in the numbers of MHCUs. ${ }^{[7]}$

The inequity in mental healthcare in Gauteng, both between mental and general health and between community and hospital psychiatric care, is not unique to this province. ${ }^{[4,5]}$ As Recommendation 16 recognises, SA as a whole must now catch up on funding community mental health services after two decades of deinstitutionalisation. The mental healthcare budget is currently insufficient, and is still being financed along historical, institution-based principles. While the role of specialised psychiatric hospitals must not be underestimated, if SA is to provide accessible, human rights-focused, equitable psychiatric care, it cannot do so without community mental health services.

\section{Lesley J Robertson, Bernard Janse van Rensburg,} Mvuyiso Talatala

South African Society of Psychiatrists, Johannesburg, South Africa lesley.robertson@wits.ac.za

\section{Cassey Chambers}

South African Depression and Anxiety Group, Johannesburg, South Africa

\author{
Charlene Sunkel, Bharti Patel \\ South African Federation for Mental Health, Johannesburg, \\ South Africa
}

\section{Sasha Stevenson}

SECTION27, Johannesburg, South Africa

\footnotetext{
1. Makgoba MW. The report into the 'Circumstances surrounding the deaths of mentally ill patient: Gauteng Province'. South Africa: Office of the Health Ombud, 2017. http://healthombud.org.za/reportinto-the-circumstances-surrounding-the-deaths-of-mentally-ill-patients-gauteng-province/ (accessed into-the-circum

2. Lazarus R. Managing de-institutionalisation in a context of change: The case of Gauteng, South Africa. S Afr Psychiatry Rev 2005;8(2):65-69. https://www.ajol.info/index.php/ajpsy/article/view/30186/22805 (accessed 11 April 2018).
} 
3. South Africa. Mental Health Care Act No. 17 of 2002. https://www.gov.za/sites/www.gov.za/files/a17 02.pdf (accessed 7 April 2018)

4. Lund C, Petersen I, Kleintjes S, Bhana A. Mental health services in South Africa: Taking stock. Afr I Psychiatry 2012;15(6):402-405. https://doi.org/10.4314/ajpsy.v15i6.48

5. National Department of Health, South Africa. National Mental Health Policy Framework and Strategic Plan 2013 - 2020. Pretoria: NDoH, 2012.
6. World Health Organization. Mental Health Atlas, 2014. Geneva: WHO, 2015.

7. Robertson LJ, Szabo CP. Community mental health services in southern Gauteng: An audit using Robertson LJ, Szabo CP. Community mental health services in southern Gauteng: An audit using
District Health Information Systems data. S Afr J Psychiatry 2017;23:a1055. https://doi.org/10.4102/ sajpsychiatry.v23i0.1055

S Afr Med J 2018;108(5):362-363. DOI:10.7196/SAMJ.2018.v108i5.13223 